Piotr Roszak ${ }^{1}$

0000-0002-2723-2667

Uniwersytet Mikołaja Kopernika, Toruń

\title{
Antropologiczne wątki rytu hiszpańsko-mozarabskiego z perspektywy euchologii In initio anni
}

Z tekstów liturgicznych zawsze wyłania się pewien obraz człowieka w jego celebracyjnej relacyjności do Boga i do całej wspólnoty, a jednocześnie skrywają one konkretną wizję życia i wartości. Ten antropologiczny potencjał obecny jest jednak nie tylko w euchologii, ale w samym akcie kultu, który obejmuje człowieka w jego duchowo-cielesnej naturze ${ }^{2}$. Ta podstawowa logika antropologiczna wyznacza jednak różne wersje praktyk pobożnych, od devotio moderna z jej podkreślaniem priorytetu myślnej modlitwy po charyzmatyczne uwielbienia, nacechowane emocjonalnością i rolą zewnętrznych znaków ciała, gestów, tańców. Dlatego nie dusza sprawuje liturgię ani samo ciało, ale cały człowiek, który kierując się ku Bogu, zdobywa, na sposób liturgiczny, głębokie Jego poznanie: w ten sposób zyskuje wiedzę dostępną na sposób rytualny czy

1 Adiunkt w Katedrze Teologii Fundamentalnej i Dogmatycznej na Wydziale Teologicznym UMK w Toruniu; profesor stowarzyszony Uniwersytetu Nawarry w Pampelunie. E-mail: piotr.roszak1@wp.pl.

2 Feria IV in prima hebdomada Quadragesima, alia: „Quo tam anima quam corpore praeparati, sancto altario tuo ministrare mereamur illaesi". 
wręcz, jak się ostatnio przyjęło określać, „wiedzę rytualną”3. Z drugiej strony trudno nie dostrzec $\mathrm{w}$ tekstach liturgicznych odniesień do panujących teorii antropologicznych, które nie zawsze w całej rozciągłości oddawały prawdy chrześcijańskiej wiary. Stąd wyczuwa się w euchologii wielu rodzin liturgicznych implicytną krytykę redukcjonistycznych ujęć: od manichejskiej pogardy dla materialności i cielesności przez różne mutacje neoplatońskie, przesuwające wyłączny akcent na sferę duchową po czysto materialistyczne podejście sprowadzające wszystko do immanentnych korzyści na wzór autoterapii ${ }^{4}$.

Hiszpańsko-mozarabska euchologia obfituje w inspirujące opisy ludzkiej natury, które nie są zebrane w jednym formularzu mszalnym, ale wymagają skupienia na rozproszonych w wielu miejscach syntagmach (wyrażeniach) o bogatym przesłaniu filozoficznym. Antropologia rytu hiszpańskiego jest przede wszystkim pozytywna, daleka od gnostyckich czy manichejskich poglądów, które odrzucałyby materię i świat, zalecając od nich ucieczkę w elitarną duchowość pneumatyków. Realizm modlitw hiszpańskich, prośby wyrażające troskę o cielesną stronę człowieka, zewnętrzne okoliczności życia (pokój, bezpieczna podróż, brak oszustw i kradzieży, zawiści wrogów etc.), towarzyszenie jego wzrastaniu fizycznemu (tak widoczne w błogosławieństwach ${ }^{5}$ na poszczególne

3 W tym kontekście warto przytoczyć klasyczne rozróżnienie na wiedzę teoretyczną i praktyczną, którą dostrzegają zarówno najnowsze ujęcia liturgii jako theologia prima, jak i filozoficzne próby opisu doświadczenia liturgicznego, np. N. Wolterstorff, Knowing God liturgically, "Journal of Analytic Theology” 4 (2016), s. 1-16. Por. także T. Dekert, Filozofia rytuału. Problemy podejścia racjonalistycznego, w: Znaki tajemnicy. Sakramenty w teorii i praktyce Kościoła, red. K. Porosło, R. J. Woźniak, Kraków 2018, s. 167-190.

4 Nie jest to przy tym jedynie historyczny relikt, bo wszystkie niemal herezje starożytne odżywają w nowych mutacjach w kolejnych epokach, a ostatnie dokumenty papieża Franciszka, w których pojawia się ostrzeżenie przed pelagianizmem w nowej postaci, tylko to potwierdzają (choćby adhortacja Gaudete et exsultate). Ciekawie o tym zjawisku w kontekście tajemnicy Kościoła i paradygmatu inkarnacyjnego pisał S. Zatwardnicki, Kościół zgorszenia - tajemnica obrazy, Katowice 2018, s. 36.

5 Warto zwrócić uwagę, że błogosławieństwo jest nie tyle sprawą życzenia, ile cechuje się mocą sprawczą: jak podkreślał Akwinata, gdy Bóg błogosławi nas, to sprawia w nas dobro, które się dopełni w przyszłości, w pewnej mierze ujawnia je i wskazuje, że dane rzecz czy wydarzenie mogą stać się zaczątkiem dobra. Por. Tomasz z Akwinu, In Hebr., cap.. „Benedictio nihil aliud est quam factio bonitatis in nobis: quae quidem in praesenti fit imperfecta sed in futuro erit perfecta". 
etapy życia człowieka, począwszy od błogosławieństwa pierwszej brody na rozpoczęcie nauki ${ }^{7}$, błogosławieństwo łoża małżeńskiego ${ }^{8}$ po związane z obrzędami pogrzebowymi ${ }^{9}$ ) - wszystko to stanowi ramy antropologiczno-teologiczne, może nie zawsze uświadomione, euchologii tej liturgii.

Wydobycie owych antropologicznych treści musi jednak przebiegać dwukierunkowo, czyli pozostać odczytane na dwóch planach: uwzględnienia filozoficznego kontekstu, w jakim rozwijała się liturgia hiszpańska (dyskusji z pryscylianizmem i arianizmem, oba nurty o charakterze dualistycznym, często oparte o matryce manichejskie i gnostyckie) oraz bazowania na treści samej euchologii ${ }^{10}$, która wskazuje na ideał duchowy, środowisko wzrastania człowieka, współpracę natury i łaski. Za kryterium podziału dla refleksji na temat człowieka w liturgii hiszpańskiej warto również przyjąć antropologię indywidualną, a więc jaką wizję natury ludzkiej się zakłada w modlitwach, oraz wspólnotową, czyli jak postrzega się wspólnota celebrująca liturgię, a ta często określa siebie jako plebs $^{11}$, populus ${ }^{12}$, conventus ${ }^{13}$, gromadzący się w świątyni będącej domus disciplinae, $\mathrm{z}$ całym bogactwem terminu disciplina wskazującym na kształtowanie samego siebie pod wpływem czynników zewnętrznych.

Dla zrozumienia natury człowieka, jaką zakłada euchologia mozarabska, warto za punkt wyjścia obrać formularz mszy odprawianej na początku roku kalendarzowego. Jest ona szczególna, gdyż wyraża prośby w obliczu otwierającego się nowego czasu, a więc wskazuje na decyzje, jakie podejmuje człowiek wierny Bogu, w nadchodzącym okresie życia kierując się pewną wizją siebie samego i swego życia. Splatają się

6 Ordo super eum que barbam tangere cupit.

7 Oratio super paruulum quem parentes ad doctrinam offerunt.

8 Ordo ad talamum benedicendum.

9 Ordo in finem hominis diei.

10 Warto w tym miejscu zaznaczyć, że jeśli nie podano inaczej, teksty euchologiczne pozostają zaczerpnięte z tekstów odnowionego rytu hiszpańsko-mozarabskiego, głównie z Missale Hispano-Mozarabicum wydanego w latach 1991-1995 oraz Liber Ordinum en usage dans l'Église wisigothique et mozarabe d'Espagne du V au X s., ed. M. Ferotin, Paris 1904. Więcej na temat sytuacji tekstów odnowionej liturgii hiszpańskiej por. F. M. Arocena, Ryt hiszpańsko-mozarabski, „Roczniki Liturgiczno-Homiletyczne” 1 (2010), s. 5-15.

11 In XI Dominico, illatio.

12 In quinto Dominico Quadragesimae, illatio.

13 In Octava Paschae, ad orationem dominicam. 
w niej dziękczynienie za przeżyty ubiegły rok z prośbą w obliczu nieznanego czasu, który ma przyczynić się do osiągnięcia przez człowieka wpisania do księgi życia, a więc pomóc przyjąć tajemnicę zbawienia i ją zaktualizować.

\section{Chronozofia liturgiczna}

Msza In initio anni jak w soczewce skupia podstawową wizję czasu (chronozofię) ${ }^{14}$, która stanowi współrzędne dla przeżywania liturgii Kościoła. To pierwsza charakterystyka człowieka, jaka wybrzmiewa w liturgii: zanurzony w czasie, człowiek przez anamnezę ${ }^{15}$ staje się uczestnikiem zbawczych wydarzeń poprzez obecność Chrystusa, prawdziwego Boga i prawdziwego człowieka, który jest „naszym pokojem i miłością niepodzielną”, jak kończą się często modlitwy ad pacem w odnowionym rycie hiszpańskim. Niepodzielność dotyczy formy miłości, która nie zamyka się w historycznych uwarunkowaniach wcielenia, nie dzieli się na miłość Boga i bliźniego, ale stanowi organiczną jedność.

Natomiast w illatio tej mszy (odpowiednik rzymskiej praefatio) zwraca się uwagę na stworzony charakter czasu, którego znaczenie kryje się w planie Boga, aby „rozwinął się” (evolutus) człowiek. Wieczny Bóg stwarza różnorodność pór roku, następowalność ich po sobie, aby człowiek doświadczał drogi doskonałości swej wolności pośród różnorodności chcianej przez Boga. Punktem wyjścia jest jednak przekonanie, że Chrystus jako początek i koniec jest stwórcą czasu - chronokratorem. Dlatego euchologia określa Go jako „zwierzchnika wszelkiej mocy” (caput omnis principatus), niezmiennego i którego czas się nie kończy. Czas nie jawi się jako pułapka, ale droga do pełni. W dokonywanych w teraźniejszości wyborach pojawia się cień wieczności: oba wymiary zostały

14 Doskonałym odniesieniem do rozważań na temat czasu i kultury, nie bez znaczenia dla rozumienia tajemnicy liturgii, jest M. Szulakiewicz, Czas i to, co ludzkie. Szkice z chronozofii i kultury, Toruń 2011, zwłaszcza diagnoza dotycząca wpływu refleksji o czasie na antropologię na s. 100-104.

15 Por. D. Brzeziński, Chrystus wczoraj i dziś, i na wieki. Anamnetyczny wymiar roku liturgicznego, Toruń 2010. 
rozszczelnione przez wcielenie Chrystusa (bożonarodzeniowy kontekst tej euchologii zdaje się na to wskazywać).

Warto zauważyć, że w obliczu sporów z pryscylianizmem (zakładającym antagonizm między tym, co stworzone, a Bogiem) i gnostycyzmem euchologia hiszpańska w swym ogólnym wydźwięku zdecydowanie afirmuje świat i czyni to nawet w kontekście postu, który dla autorów tekstów liturgicznych był już w raju i nie jest karą za grzechy, ale sposobem czuwania nad otrzymanym darami i ich rozwojem, a więc drogą do pełnej wolności i doskonałości. Dlatego celem postu jest zdobycie salus przez ciało, a vis divina przez duszę ${ }^{16}$, a przy tym cechuje ją delikatność w stosunku do świata. Z modlitw płyną wezwania do wiernych, aby nie eksploatowali stworzenia, rozumiejąc biblijne zaproszenie do czynienia sobie ziemi poddanej (Rdz 1, 28) w kategoriach agresywnego posiadania, lecz respektując jego sakramentalność, a więc fundamentalne ukierunkowanie na Stwórcę. Dlatego w jednej z modlitw słychać wołanie:

Teraz, gdy święte i wspólne uczucie zgromadziło nas na modlitwie, przedstawiamy Ci Boże Ojcze nasze pokorne modlitwy; Ty, który uświęciłeś bieg czasu wraz z narodzinami Twego Syna, udziel nam roku pokoju, abyśmy mogli poświęcić dni nasze na Twoją służbę. Napełnij ziemię Twoimi darami, uwolnij nasze ciała od chorób, a nasze dusze od grzechu. Oddal od nas niespodziewane przeciwności (dosł. scandala), zniszcz moc złego, wyzwól nas od biedy, oddal od naszego kraju wszelkiego rodzaju zła ${ }^{17}$.

Czas nie jest więzieniem dla człowieka, ale wymiarem i sposobem jego bycia w świecie. Tym, o co prosi człowiek u progu rozpoczynającego się czasu, jest najpierw pozytywne obdarowanie, a potem dopiero usunięcie tego, co ogranicza. Czy to również wskazanie na naturę człowieka?

16 In primo Dominico Quadragesimae, id est, de carnes tollendas, alia.

17 In initio anni, illatio. Wszystkie tłumaczenia tekstów euchologii hiszpańskiej są własne. 


\subsection{Hiszpańsko-mozarabskie rozumienie natury ludzkiej}

Gdy w euchologii hiszpańsko-mozarabskiej mówi się o ludzkiej naturze, podkreśla się jej kruchość (fragilitas) ${ }^{18}$, podatność na zranienie (comprehensibilis in vulnere), która jednak nie przeszkadzała męczennikom złożyć ofiarę Chrystusowi z własnego życia, choć jej słabość wprowadza lekki zamęt nawet w postawie św. Cypriana, o czym wspomina prefacja (illatio) na jego święto. Ale jednocześnie liturgia wskazuje na jej racjonalny i zarazem śmiertelny charakter, na potrzebę jej odnowienia przez łaskę, gdyż stała się vitiat a natura ${ }^{19}$. Często rozważania nad naturą ludzką związane są z wyjaśnieniem tajemnicy Chrystusa, Jego prawdziwego człowieczeństwa. Przyjście Chrystusa związane jest z odkupieniem „kruchości ludzkiej”, zniżeniem się do naszej „słabości” (miseria) i uzdolnieniem jej do czynów przekraczających jej moc. Dla autorów modlitw łaska jest udzieloną przez Boga „mocą” darowaną naturze, aby pomimo swej słabości była w stanie dokonać czynów ją przekraczających ${ }^{20}$. Łaska nie jest więc stanem hibernacji natury czy jej zamrażania, ale rozkwitu mocy i działania ponad jej miarę. Widać wyraźnie, że nie wyrywa ona człowieka zjego świata, ale pozwala mu przeżywać swój czas na ziemi w całej pełni, w komunii z Bogiem.

Wizja, jaką roztacza euchologia mozarabska, to wskazanie na człowieka jako potrzebującego, a nie samozadowolonego i zakończonego: rytm roku liturgicznego upływa bowiem na dojrzewaniu do tajemnicy, która w pełni jaśnieje w czasie nocy paschalnej (taki jest sens okresu wielkanocnego i adwentu). W tym ujęciu Bóg nie jawi się jako stojący na antypodach człowieka, ale jako najbardziej intymny dla swego stworzenia, co tak dobitnie podkreślają zwłaszcza modlitwy post nomina (odpowiednik rzymskiej modlitwy powszechnej), mówiące o Bogu, że jest „życiem żyjących" (vita vivorum) ${ }^{21}$.

18 Co wyraźnie wybrzmiewa w obrzędach pogrzebowych, gdzie mowa jest o przejściu przez świat, por. P. Roszak, Spanish-Mozarabic funeral rituals: a contribution to the eschatology of the rite, "Quaestiones Medii Aevi Novae" 21 (2016), s. 207-225.

19 In tertio Dominico Quadragesimae, alia.

20 In sexto Dominico Paschae, post sanctus.

${ }_{21}$ Cała formuła brzmi następująco: „Quia tu es vita vivórum, sánitas infirmórum ac réquies ómnium fidélium defunctórum in ætérna sæcula sæculórum”. 
W czasie mszy wielkiego postu liturgia hiszpańska modli się do Boga, który jest „stworzycielem i odnowicielem życia ludzkiego”. Natura nie jest elementem niezależnym od Boga i Jego łaski, ale z niej wypływającym, cieszącym się wolnością i oczekującym na ostateczne swe ukierunkowanie. Liturgia jest sposobem pielęgnowania tej natury, aby rozkwitała, i przygotowaniem, aby ciała nasze zostały uwielbione przez Chrystusa. To zgoda na Jego odnawiające działanie, zarówno dotykające słabości ciała, jak i dolegliwości duszy.

Pojęcie natury ludzkiej w rycie hiszpańskim nie jest więc statyczne, ale zakłada rozwój, dojrzewanie do pełni ${ }^{22}$, co wybrzmiewa szczególnie w tekstach wielkopostnych, z których wyłania się obraz postu jako przywracania równowagi egzystencjalnej, a tym samym porządku, jaki Bóg ustanowił (stąd nacisk na poznanie tego porządku jaki był w planach Boga i został naruszony przez grzech). Nie znajdujemy w nich idei karania ciała, ale temperowanie nieuporządkowania, bo cielesność jest dla euchologii mozarabskiej sposobem obecności człowieka w świecie, epifanią jego duchowości. Trudno inaczej to ująć, skoro obecność Chrystusa w Eucharystii definiuje się poprzez „ciało”, rozumiane jako sposób bytowania w świecie, a nie abstrakcyjne formuły ${ }^{23}$. Tym samym wiąże się to z harmonizowaniem postaw człowieka „zewnętrznego" i „wewnętrznego", do której to dychotomii liturgia często powraca, niekiedy w napięciu dialektycznym afflícto exterióri hómine, dilatétur intérior. Wypływa to z wnikliwości Boga, który zwraca uwagę bardziej na ducha (mens) niż wiek (aetas), na serce bardziej niż na słowa ${ }^{24}$.

W mszy na wspomnienie św. Justy i Rufiny, męczennic z Sewilli czczonych uroczyście w liturgii hiszpańskiej, euchologia wspomina o żądzy uczuć (cupiditas incendia), które mogą zostać zahamowane poprzez cnoty.

22 Alister McGrath w Re-imagining nature: the promise of a Christian natural theology, Oxford 2017 zwraca uwagę na nieostry charakter pojęcia „natura”, który jest przez nas rozumiany pasywnie, podczas gdy jest on w pełni dynamiczny. Tomasz z Akwinu mówił o naturze jako pewnej sztuce (ars), dzięki której natura samo-organizuje się w osiąganiu celów.

${ }_{23}$ Por. J. Granados, Cuerpos sacramentales: cómo abrir espacios cristianos en la era secular, „Revista Española de Teologia” 1 (2018), s. 106.

24 Por. J. Berry, What makes us human? Augustine on interiority, exteriority and the self, „Scientia et Fides” 2 (2017), s. 87-106. 
Wszystko oczywiście nabiera znaczenia w kontekście męczeństwa, którego świadectwo złożyły obie kobiety. Z perspektywy antropologicznej owa cupiditas to wskazanie na istnienie sfery pożądawczej w człowieku, która nie jest zła sama w sobie, ale w swej nieuporządkowanej postaci. Dlatego w kierowanych do Boga prośbach nie chodzi o jej eliminowanie, ale poddanie virtus, przemieniającej mocy łaski, której skutkiem jest również pewien porządek, uhierarchizowanie celów i środków. W kontekście świąt wielkanocnych liturgia wzywa:

Uśmiercajmy nasze ciała i błędne nawyki; krzyżujmy cielesne pożądania; zmartwychwstańmy w duszy, jak ów Sprawiedliwy zmartwychwstał w chwale ${ }^{25}$.

Wezwanie dotyczy przywrócenia równowagi wewnętrznej między sprawami duchowymi a cielesnymi, niezanieczyszczanie ciała (impolluti corporis) mającego zostać przemienionym w chwale, uporządkowanie w oparciu o powołanie człowieka do nieśmiertelności i niezniszczalności (incorruptibilitas). Dokonuje się to na drodze wewnętrznych zmagań, jakie toczą się w duszy człowieka, często wewnętrznie podzielonego. $\mathrm{Z}$ tego powodu liturgia określa życie ludzkie jako certamen, walkę o życie wieczne (w której pośród trudności dokonuje się próba i wykuwa się nagroda nieba - msza Cypriana), a modlitwy proszą o ardor caritatis w sercu ${ }^{26}$.

Światło na rozumienie natury ludzkiej rzucają te teksty euchologiczne, które wspominają tajemnicę człowieczeństwa Chrystusa, czyniąc to w kontekście sporów z dominującym wówczas w Hiszpanii adopcjanizmem czy arianizmem. Te dwie nieortodoksyjne chrystologie podkreślały, że doskonałe człowieczeństwo Chrystusa w nagrodę zostało wyniesione do kondycji boskiej lub zaadoptowane przez Ojca. W takim jednak myśleniu w gruncie rzeczy uwidacznia się redukcjonistyczne podejście, które sprowadza człowieczeństwo Jezusa do naszego ${ }^{27}$. Tym bar-

25 In II feria Paschae, ad orationem dominicam: „Mortificemus cum vitiis membra nostra; crucifigamus desideria carnalia; resurgamus in anima, sicut ille iustus surrexit in gloria".

${ }^{26}$ In diem sancti Cypriani, post pridie.

27 Szerzej na temat ukrytej dyskusji z adopcjanizmem i arianizmem w tekstach euchologicznych hiszpańskich, por. J.F. Rivera, El adopcionismo en España, siglo VIII: historia y doctrina, Toledo 1980 oraz P. Roszak, Mozarabowie i ich liturgia. Chrystologia rytu hiszpańsko-mozarabskiego, Toruń 2015, s. 161-177. 
dziej więc liturgia hiszpańsko-mozarabska modli się do Chrystusa, który stał się consortem caducce carnis nostree ${ }^{28}$, przez co nawiązana została nowa forma komunikacji człowieka z Bogiem, która, jak podkreślali ojcowie Kościoła, a potem scholastyka, staje się możliwa dzięki człowieczeństwu Chrystusa.

$\mathrm{Na}$ oznaczenie duszy liturgia posługuje się określeniem anima, rzadziej alma czy mens, choć samo bogactwo tego słownika jest już znaczące i wskazuje na centrum życia osobowego i wewnętrznego. Wskazuje się, że nie chodzi o „coś” w człowieku, ale o całego człowieka w jego specyficznej formie: ciało nie jest kartezjańską res extensa, ale epifanią osoby. To właśnie rozwijaniu życia duchowego, zagrożonego zbytnim przylgnięciem do spraw doczesnych (cogitatio terrena w języku liturgii hiszpańskiej), co wyrażać się może infekcją tego, co „brzydkie”, , powierzchowne” i „próżne”29, poświęca szczególną uwagę euchologia tego rytu.

\subsection{Sens upływającego czasu: został on „konsekrowany”}

W mszy In initio anni człowiek jest tym, który przyjmuje czas i prosi o jego konsekrowanie, aby przeżył go w „,integralności duchowej”. Z tego powodu prośby, choć tak często dotyczą uwolnienia ciała od chorób, a duszy od grzechu, ogniskują się jednak na ukształtowaniu właściwej devotio. Termin ten, tłumaczony jako „pobożnośc”, jest dla euchologii hiszpańskiej charakterystyką woli człowieka chętnie podążającego za Bożym wskazaniem, przekonanego i pełnego zapału. Duch tej pobożności przekłada się na rozumienie woli Boga, bo jej spełnianie nie ma w sobie nic $\mathrm{z}$ automatyzmu lub konieczności, ale jest świadomym wyborem drogi zbawienia.

Konsekracja czasu to dla tej liturgii postawa ofiarowania, ale rozumiana jako synonim nie wyłączania z obiegu, lecz nadawania nowych odniesień, wprowadzania nowych relacji. To otwiera na przeżywanie sacrum jako „miejsca” nie tyle wyizolowanego, ile nacechowanego relacyjnością. Dlatego niczym refren pojawia się w tej mszy wezwanie, aby przeżywać czas na służbie Bogu słowem i czynem, podobając Mu się

\footnotetext{
28 In quarto Dominico Paschae, oratio admonitionis.

29 In XXII Dominico, ad orationem dominicam.
} 
we wszystkim, i by przekraczać próg nowego czasu z wychwalaniem Boga (in confessione) ${ }^{30}$.

Jaki jest jednak ostateczny sens czasu i opóźniania się pełni zbawienia, jaka wiąże się z historią i oczekiwaniem na powtórne przyjście Chrystusa? Doświadczenie czasu i kolejne pokolenia ludzi w tej wizji historii prowadzić mają do postulowanego przez Pawła zwiększania chwały Bożej przez dziękczynienie wielu (por. 2 Kor 4, 15). A więc misja Kościoła to włączanie całej ludzkości w hymn pochwalny, relację do Stwórcy. To także czas wolnej odpowiedzi na współpracę z łaską (w teologicznym słowniku tradycja katolicka nazywa to „zasługą”, zawsze pozostającą darem Boga), o której aniołowie zdecydowali w jednym momencie historii, zaś człowiek dokonuje w ciągu swego całego życia.

Na określenie skutków celebracji euchologia hiszpańska koncentruje uwagę na odpuszczeniu grzechów i zbawieniu duszy (sanitas mentis) ${ }^{31}$. Liturgia dysponuje czy kształtuje ciało i wychowuje je do głębszej wolności niż tylko samopanowanie nad instynktami, gdyż wskazuje na umiejętność daru, sztukę dobrego życia polegającego na wytrwałości pośród trudności (tribulatio), z której rodzi się wolność. Euchologia hiszpańska nie neguje związanego z tym trudu, wręcz zaskakuje realizmem języka, jakim definiuje potencjalne trudności człowieka na tej drodze. To nie język metafizycznych kategorii, lecz konkretnych wyzwań (obojętność itd.). Ideałem stawianym $\mathrm{w}$ tekstach jest przejście nietkniętym, niezabrudzonym przez życie (de hoc sœeculo nequam eripiámur illœesi ${ }^{22}$ ), ale także fakt, że życie człowieka rośnie pośród trudności (inter adversa crescere), co domaga się pielęgnowania postawy współcześnie określanej mianem rezyliencji, a więc umiejętności wzrastania w obliczu niesprzyjających okoliczności. To nie tylko kwestia opanowania stresu czy radzenia sobie ze smutkiem, ale inicjowanie procesów, które w długoterminowej perspektywie prowadzą do osiągnięcia szczęścia. Prośby dotyczą uwolnienia od zewnętrznych wrogów i niebezpieczeństw (zwłaszcza obfitują w takie wezwania modlitwy np. nad pielgrzymami), ale także ograniczeń

\footnotetext{
30 In initio anni, post sanctus.

31 In XVI Dominico, completuria.

32 In initio anni, benedictio.
} 
i zaburzeń, jakie w życie wprowadza grzech. Rozstrojenie, które on wprowadza, jest w stanie zestroić na nowo jedynie łaska.

\subsection{Uczucia „celebracyjne”? Styl euchologii hiszpańskiej a realistyczna prawda o człowieczeństwie}

Antropologiczne przesłanie rytu kryje się nie tylko w słowach modlitw, ale także w ich stylu, odwołującym się do natury człowieka oraz samej strukturze świętych obrzędów, w których np. pojawia się modlitwa post nomina, będąca błyskiem świadomości eklezjologicznej. Poleca się w niej zmarłych i żywych. Nade wszystko jednak pierwsza osoba liczby mnogiej wielu modlitw wyraża świadomość eklezjalnego „my”.

Znaczące jest to, jak często euchologia odwołuje się do affectio, którą pragnie kształtować liturgia: pod tym terminem kryje się wola pełna wdzięczności wobec Boga i zawsze wobec Niego ukierunkowana (stąd dookreślenia pia, sollicita ${ }^{33}$ w stosunku do affectio). To termin, który wskazuje nie tyle na spontaniczną uczuciowość, ile poprzedzone wyborem przylgnięcie do Pana, postawę otwarcia na Jego dar, widziane jako przeciwieństwo zasługi ${ }^{34}$.

Zwraca uwagę także inny element doniosły antropologicznie: podkreślanie przez liturgię znaczenia „pragnienia”, wyrażanego za pomocą terminu vota. Chodzi o rozbudzanie tych pragnień, aby nie zgasły, umacniane przykładem świętych (co wyraża euchologia mszy ku czci św. Cypriana), inspirowanie ich, aby sięgały nieśmiertelności, sprawdzanie ich autentyczności przez Pana (proba vota) to tematy wielu modlitw rytu. Pragnienie nie tylko zdradza, co faktycznie interesuje człowieka, ale jest formą jego wzrastania, ratyfikowaniem drogi proponowanej przez łaskę, która kieruje ku życiu wiecznemu. Jednocześnie te postanowienia decydują o charakterze zwykłej wędrówki: gdy liturgia przyzywa błogosławieństwa Bożego nad pielgrzymami czy udającymi się w drogę, to przywołuje właśnie pobożne pragnienia (z całym bogactwem znaczenia cnoty pobożności), których realizacja wiąże się

33 In sexto Dominico Paschae, oratio admonitionis.

34 In IV feria Paschae, oratio admonitionis. 
z pewną ofiarą. Owe vota to postanowienia nie krótkoterminowe, ale mające zasięg eschatologiczny. Dlatego w illatio opowiadającej o spotkaniu Jezusa z Samarytanką akcent jest położony na „święte pragnienia”, o które się prosi w euchologii wraz z tym, by „z Twoją pomocą w tych dniach świętych, nie zabrudziły nas uczucia, nie opanowała złość i nie podzielił nas grzech" ${ }^{35}$.

W przeciwieństwie do euchologii pochodzących z innych tradycji liturgicznych ryt hiszpańsko-mozarabski cechuje również specyficzny styl narracji modlitwy. Zawierają krótkie wyrażenia i powtórzenia oraz tchną realizmem rozmowy, zdradzając uczucia im towarzyszące. Modlitwy te nie mają w sobie nic z chłodnych kalkulacji filozofa, ale wyrażają życie kształtowane przez liturgiczne spotkanie z Panem, z których niczym z mozaiki można ułożyć zasadnicze wymiary ludzkiego życia:

Prosimy Cię, Boże Ojcze, aby na tej drodze, którą rozpoczynamy, spoczęło na nas Twoje spojrzenie, aby nie było podwójności w naszym sercu, ani byśmy nie ranili naszych przyjaciół kłamstwami, aby w naszym życiu nie było miejsca na nieumiarkowane pragnienie pokarmu, ani nie splamiło się zgodą na cielesne żądze, ale by nie upadło pod ciężarem postu ani nie wystawiało się na pokusy próżności, ani nie wpadło w nieuporządkowanie nienawiści, ani nie zatopiło w tym, co najniższe ze względu na pragnienie bogactw ${ }^{36}$.

\section{2. „Obieg” antropologiczny: między jednostkowością a wspólnotowością}

Ostatnimi czasy wzrasta zainteresowanie tematyką „domyślnej antropologii”, jaką zakłada liturgia w wielu swych przejawach ${ }^{37}$, zastanawiając się nad stawianą w niej kwestią relacji jednostki do wspólnoty, która sprawuje święte obrzędy. Czy to zatopienie w tłumie i utrata tożsamości, czy też zachowana jest indywidualność bez jej monadycznej ceny?

35 In secundo Dominico Quadragesimce, alia.

36 Missa ieiunii de II feria inchoante Quadragesima, illatio.

37 W. Engemann, How People Are Treated During Worship: Problems of an Implicit Liturgical Anthropology, „International Journal of Practical Theology” 2 (2017), s. 259-280. 
Zdecydowana większość tekstów euchologii hiszpańskiej wyrażana jest w „my” liturgicznym, które rozpoznaje się w każdym poszczególnym uczestniku. To efekt podkreślanej tak mocno w rycie scalającej siły „niepodzielnej miłości-caritas” (cáritas indisrúpta) ${ }^{38}$ oraz więzi jedności, która prowadzi do zgody. Z historycznego punktu widzenia można widzieć tu kontekst podziałów wśród chrześcijan ariańskich i katolickich, ale bez wątpienia refleksja może zostać usytuowana na planie nie tyle apologetycznym, ile metafizycznym, który podkreśla relacyjność człowieka. Wyrażają to określenia wspólnoty celebrującej liturgię, takiej jak turba, familia tua, populus, conventus dominicce plebis et coadunatio christiance religionis, a więc terminy zmierzające do ukazania Kościoła jako zebrania ludu Pana i ludu chrześcijańskiego ${ }^{39}$. Dynamikę życia tej wspólnoty oddaje pojawiające się często $w$ tekstach convenire, gromadzenie się na Boże zwołanie, każdy z własnej perspektywy i sytuacji życiowej, w bogactwie stanów i powołań:

Wy, zebranie ludu Pana i zgromadzenie wiernych, uwolnijcie przed Panem wasze serca, przedstawcie Wasze problemy, spełnijcie wasze obietnice. Bo Ten, który z uwagą spogląda na afekt waszej prośby, przyjmie ofiarę waszego postu. Im bardziej się upokorzymy pod ręką mocnego Boga, tym więcej pomoże nam podnieść się w chwili utrapieńt ${ }^{40}$.

Postawę wspólnoty celebrującej liturgię definiuje nie tyle socjologiczny opis, ile teologiczne wskazanie, że życie toczy się in respectu Dei. Ale stanie przed obliczem Boga to nie zwykła obecność jeden naprzeciwko drugiego, ale orędownictwo wyrażające się w recytowaniu imion świętych. Jest to przypomnienie o pełnym wymiarze Kościoła, który stanowią pielgrzymujący i zbawieni w niebie. Wspólnota nie pozostaje tylko w horyzontalnym układzie odniesień, lecz wskazuje eschatologiczny kierunek życia in concilio sanctorum, ku pełnej realizacji bycia współobywatelami świętych (por. Ef 2,19).

Natomiast wśród wielu powiązań między uczestnikami liturgii a świętymi podkreśla się możliwość uczestnictwa w ich zasługach. To motyw,

38 In V Dominico, ad pacem.

39 Feria IV in quarta hebdomada Quadragesimee, oratio admonitionis.

40 Feria IV in quarta hebdomada Quadragesime, oratio admonitionis. 
który najczęściej pojawia się w mszach o męczennikach, gdy liturgia prosi o możliwość złączenia się z ich zasługami, a wydźwięk czasowników jest niezwykle mocny (meritis copulemur - msza we wspomnienie Justy i Rufiny). Dobre czyny nie zostają odległym przykładem, ale ponieważ doprowadziły do zjednoczenia z Bogiem, mają moc rezonowania w życiu kolejnych pokoleń wierzących dzięki liturgicznej solidarności, wymianie czy perychorezie. Dobro nie ginie wraz ze śmiercią świadka, ale staje się zaczynem kolejnego: śladem, który nie jest reliktem, ale cieszy się sprawczością, choć nie autonomiczną, lecz uczestniczącą. Chodzi o sposób, w jaki Bóg udziela łaski, włączając w to świętych.

Z kolei liturgiczne podstawy metafizyki wspólnoty wiążą się z udziałem w łasce chrztu i nowego życia, a jedność rodzi się z przyjęcia miłości Chrystusa, która jest więzią łączącą wszystkich w jednym ciele. Ta duchowa, a nie fizyczna styczność wyraża się w dążeniu do bycia unanimes atque concordes ${ }^{41}$ również $\mathrm{w}$ poczuciu odpowiedzialności za popełniane zło, które rani wspólnotę.

\section{Podsumowanie}

W oparciu o wybrane teksty euchologii rytu hiszpańskiego zostały ukazane podstawy wizji antropologicznej tkanej przez modlitwy tej liturgii. Akcentuje ona wartość ludzkich pragnień (vota credentium, desideria), które powinny zostać właściwie ukształtowane, aby wzrastał człowiek wewnętrznie i przemieniał zewnętrzne wyrazy swej osobowości. Kierunek odnowy prowadzi w duchu tej liturgii od wnętrza na zewnątrz i w tym świetle można dopiero odkryć znaczenie tradycyjnych praktyk duchowych, takich jak post, który odgrywa ważną rolę w duchowości hiszpańsko-mozarabskiej: dotyka serca, jego uporządkowania i wolności (jest „medycyną duszy”). To realistyczna wizja człowieka, którego cielesność jest czymś dobrym, choć w skutek grzechu pierworodnego często wpada w moc instynktów i potrzebuje dostrojenia do tej pełni człowieczeństwa, jaka ujawnia się w Chrystusie,

\footnotetext{
${ }^{41}$ In VIII Dominico, benedictio.
} 
doskonałym człowieku. Nie ma ono charakteru jedynie zewnętrznego wzorca (exemplum), ale stanowi zasadę przemiany (exemplar w języ$\mathrm{ku}$ scholastyki). Człowiek rozpoznaje i wyznaje w modlitwach rytu, że jest homo necessitans, potrzebującym, a nie samowystarczalnym, a nie tyle go poniża, ile odsłania drogę dojrzewania do pełni przez otwarcie na moc odradzającej łaski. 


\section{Summary}

\section{Antropologiczne wątki rytu hiszpańsko-mozarabskiego z perspektywy euchologii In initio anni}

Teksty euchologiczne rytu hiszpańsko-mozarabskiego kryją w sobie wiele wątków antropologicznych, które są rezultatem okoliczności historycznych, $\mathrm{w}$ jakich kształtowała się liturgia na Półwyspie Iberyjskim (dyskusje z arianizmem, adapcjanizmem czy pryscylianizmem). Artykuł składa się z dwóch części: w pierwszej zostaje przeanalizowany formularz mszy na rozpoczęcie roku w rycie hiszpańskim, który wydobywa ramy chronozoficzne refleksji nad człowiekiem w dynamizmie stawania się i jego największych aspiracji. Następnie w drugiej części przywołuje się mozarabskie rozumienie natury ludzkiej i jej relacji do łaski Bożej, cielesności i duchowości, aby skupić się na wybranych kategoriach antropologicznych, takich jak affectio, devotio czy vota, wokół których konfiguruje się antropologia (indywidualna i wspólnotowa) rytu hiszpańskiego.

Słowa kluczowe: pryscylianizm, arianizm, natura, łaska

\section{Anthropology of Hispanic-Mozarabic Rite in Perspective of In initio anni Eucology}

Eucological texts of the Spanish-Mozarabic Rite contain many interesting anthropological insights which are the result of historical circumstances in which liturgy took shape on the Iberian Peninsula (discussions with Arianism, Adaptionism or Priscilianism). The article consists of two parts: the first one examines the texts from the Mass for the beginning of the year (in initio anni) in the Spanish rite, which brings out the cronosophical framework of reflection on man in his dynamics of becoming and his greatest aspirations. The second part is devoted to the Mozarabic understanding of human nature and its relation to God's grace, corporality and spirituality in order to focus on some anthropological categories, such as affectio, devotio or vota, around which individual and communal anthropology of the Spanish rite is grounded.

Keywords: Priscilianism, Arianism, nature, grace

\section{Bibliografia}

Arocena F. M., Ryt hiszpańsko-mozarabski, „Roczniki Liturgiczno-Homiletyczne” 1 (2010), s. 5-15.

Berry J., What makes us human? Augustine on interiority, exteriority and the self, „Scientia et Fides” 2 (2017), s. 87-106. 
Brzeziński D., Chrystus wczoraj i dziś, i na wieki. Anamnetyczny wymiar roku liturgicznego, Toruń 2010.

Caballer A., La Historia de la Salvación, a través del Antiguo Testamento de la Cuaresma, en las tradiciones A y B del Rito Hispánico, Valencia 2018.

Dekert T., Filozofia rytuału. Problemy podejścia racjonalistycznego, w: Znaki tajemnicy. Sakramenty w teorii i praktyce Kościoła, red. K. Porosło, R. J. Wozniak, Kraków 2018, s. $167-190$.

Engemann W., How People Are Treated During Worship: Problems of an Implicit Liturgical Anthropology, „International Journal of Practical Theology” 2 (2017), s. 259-280.

Liber Ordinum en usage dans l'Église wisigothique et mozarabe d'Espagne du V au X s., red. M. Ferotin, Paris 1904.

Granados J., Cuerpos sacramentales: cómo abrir espacios cristianos en la era secular, „Revista Espanola de Teologia” 1 (2018), s. 101-126.

McGrath A., Re-imagining nature: the promise of a Christian natural theology, Oxford 2017.

Rivera J. F., El adopcionismo en Espana, siglo VIII: historia y doctrina, Toledo 1980.

Roszak P., Mozarabowie i ich liturgia. Chrystologia rytu hiszpańsko-mozarabskiego, Toruń 2015.

Roszak P., Spanish-Mozarabic funeral rituals: a contribution to the eschatology of the rite, "Quaestiones Medii Aevi Novae" 21 (2016), s. 207-225.

Szulakiewicz M., Czas i to, co ludzkie. Szkice z chronozofii i kultury, Toruń 2011.

Wolterstorff N., Knowing God liturgically, ,Journal of Analytic Theology" 4 (2016), s. $1-16$.

Zatwardnicki S., Kościół zgorszenia - tajemnica obrazy, Katowice 2018. 